\title{
Vitamin D Status and the Determinants of Preeclampsia in Pregnant Women in Goma (Democratic Republic of the Congo)
}

\author{
Kabuyanga Kabuseba Richard ${ }^{1}$, Balungwe Sifa Marcelline², Elongi Moyene Jean-Pierre ${ }^{3}$, \\ Lundimu Tugirimana Pierrot ${ }^{4}$, Kalenga Muenze Kayamba Prosper ${ }^{5}$, \\ Kakoma Sakatolo Zambeze Jean-Baptiste ${ }^{5}$
}

\author{
${ }^{1}$ Department of Gynecology-Obstetrics, University of Goma, Goma, DR Congo \\ ${ }^{2}$ Department of Gynecology-Obstetrics, Evangelical University in Africa, Bukavu, DR Congo \\ ${ }^{3}$ Department of Gynecology-Obstetrics, General Hospital of Kinshasa, Kinshasa, DR Congo \\ ${ }^{4}$ Department of Laboratory \& Basic Sciences, University of Goma, Goma, DR Congo \\ ${ }^{5}$ Department of Gynecology-Obstetrics and School of Public Health, University of Lubumbashi, Lubumbashi, DR Congo \\ Email: docrica@hotmail.com
}

How to cite this paper: Richard, K.K., Marcelline, B.S., Jean-Pierre, E.M., Pierrot, L.T., Prosper, K.M.K. and Jean-Baptiste, K.S.Z. (2020) Vitamin D Status and the Determinants of Preeclampsia in Pregnant Women in Goma (Democratic Republic of the Congo). Open Journal of Obstetrics and Gynecology, 10, 820-835.

https://doi.org/10.4236/ojog.2020.1060077

Received: May 16, 2020

Accepted: June 27, 2020

Published: June 30, 2020

Copyright $\odot 2020$ by author(s) and Scientific Research Publishing Inc. This work is licensed under the Creative Commons Attribution International License (CC BY 4.0).

http://creativecommons.org/licenses/by/4.0/ (c) (i) Open Access

\begin{abstract}
Background: Preeclampsia (PE) is a common condition, causing maternal and perinatal morbidity and mortality worldwide. In the absence of fully satisfactory treatment, screening remains one of the pillars of management. Low vitamin D status has been identified as a risk factor for PE. But, data on vitamin D status and risk factors for PE in the Democratic Republic of the Congo (DRC) is scanty. The aim of this study is to determine the level of Vitamin D and risk factors in preeclamptic patients in our environment. Methods: To fill this gap, we conducted a multicenter incident case control study on 190 pregnant women, 95 cases and 95 controls, receiving care from seven hospitals in Goma, in the eastern DRC, from April 1 to December 31, 2019. Socioeconomic, diet habits, clinical data, urinalysis and serum 25 -hydroxy vitamin $\mathrm{D}$ $[25(\mathrm{OH}) \mathrm{D}]$ levels were analyzed. Vitamin $\mathrm{D}$ deficiency was defined as serum $25(\mathrm{OH}) \mathrm{D}<30 \mathrm{ng} / \mathrm{ml}$. Bivariate and multivariate analysis were used to assess risk factors of PE. Results: The median vitamin D level in preeclamptic women was lower than in the control group (21.7 [Interquartile Range (IQR) $=19.2-24.1] \mathrm{ng} / \mathrm{ml}$ versus $28.5[\mathrm{IQR}=24.9-31.4] \mathrm{ng} / \mathrm{ml} ;(\mathrm{p}<0.001) . \mathrm{PE}$ was associated with: 1) vitamin D deficiency, Odds Ratio (OR) $=2.77$ at $95 \%$ Confidence Interval-CI of $[1.22-6.31] ; \mathrm{p}=0.015 ; 2)$ previous history of $\mathrm{PE}$ $(\mathrm{OR}=12.30 ; 95 \% \mathrm{CI}[1.92-18.98] ; p=0.008)$ and 3$)$ high $\mathrm{BMI}(\mathrm{OR}=2.82$; $95 \%$ CI $[1.28-6.21] ; p=0.010)$. Smoking (OR $=0.33 ; 95 \%$ CI $[0.22-0.98] ; p$ $=0.015)$ and consumption of dairy products $(\mathrm{OR}=0.39 ; 95 \% \mathrm{CI}[0.17-0.92]$; $p=0.032)$ were protective. Conclusion: The odds of PE were 3 -fold in preg-
\end{abstract}


nant women with vitamin D deficiency. Vitamin D supplementation during pregnancy might reduce the risk of developing PE and ultimately reduce the consequences on maternal and perinatal advert outcomes.

\section{Keywords}

Democratic Republic of the Congo, Vitamin D Deficiency, Preeclampsia

Determinants

\section{Introduction}

Preeclampsia (PE) is a clinical syndrome characterized by the new onset of hypertension plus proteinuria, end-organ dysfunction, or both after 20 weeks of gestation in a previously normotensive woman [1]. PE affects globally $4.6 \%$ of pregnant women [2]. The highest prevalence occurs in developing countries, reaching $18 \%$ [3]. PE is the second leading cause of maternal death and significant maternal and fetal morbidity and mortality [4].

The pathophysiology of PE is complex. Multiple etiological factors and pathways have been cited, including: abnormal development of the placenta (abnormal remodeling of spiral arteries, defective trophoblast differentiation and placental hypoperfusion, hypoxia, ischemia); immunologic, genetic and environmental factors (High body mass index, low calcium intake), inflammation (attributed to circulating syncytiotrophoblast debris); increased sensitivity to angiotensin II; complement activation and systemic response to generalized endothelial dysfunction [5] [6] [7].

Currently, there is no PE curative treatment other than delivery, none of the interventions targeting one or another factor above have shown effectiveness in PE prevention in the general obstetric population [8] [9]. In recent years, various studies suggested the association between poor vitamin D status and PE [10] [11]. In addition, vitamin D supplementation demonstrated some promising results [12].

However, in the Democratic Republic of the Congo, data on vitamin D status and the risk factors of PE are scarce. The objective of this study was to assess the association between vitamin $\mathrm{D}$ status and the determinants of PE, prior to vitamin D supplementation trial in Goma.

\section{Materials and Methods}

\subsection{Study Location}

The study was conducted in Goma, a city in the eastern Democratic Republic of the Congo, with a total population of over a million, an average annual temperature of $20.5^{\circ} \mathrm{C}$ and an annual rainfall of $1144.6 \mathrm{~mm}$ (from 1971 to 2016). The soil is essentially volcanic. There are no rivers or streams in the town due to volcanic eruptions, but rather a large lake (Lake Kivu) rich in methane gas [13]. 
Like all over the country, Goma has permanent sunshine throughout the year.

\subsection{Study Design and Sample Size}

It was a multicenter, incident, unmatched, case control study. The sample size was calculated using the formula:

$$
n=t^{2} \times p \times(1-p) / m^{2}
$$

( $n=$ minimum sample size required; $t=$ critical value for a confidence level of $95 \%$, i.e. 1.96; $p=$ estimated proportion of the population with the characteristic. ( $p=0.085)[14] ; m=$ margin of error, i.e. 0.05). So, $n$ was equal to $1.96^{2} \times 0.085 \times(1-0.085) / 0.05^{2}=119.51$ pregnant women.

\subsection{Ethics and Consent}

The purpose of the study was communicated in the local language to eligible women. Oral and written informed consents were obtained from all participants. The research project was approved by the Institutional Review Board of the University of Lubumbashi in its February 8, 2019 session (Reference ${ }^{\circ}$ UNILU/CEM/125/2019). In addition, the study was authorized by the provincial health division of North Kivu.

\subsection{Eligibility Criteria}

Inclusion criteria for cases were: pregnant women diagnosed or followed up for $\mathrm{PE}$ in one of the seven hospitals selected. PE was defined as systolic blood pressure $\geq 140 \mathrm{~mm} \mathrm{Hg}$ and/or diastolic blood pressure $\geq 90 \mathrm{~mm} \mathrm{Hg}$, taken twice at 4-hour intervals, at rest after 20 weeks of amenorrhea with proteinuria $\geq 2$ crosses or $30 \mathrm{mg} / \mathrm{dL}$ [8]. A woman attending ANC (antenatal care) visits with normal pregnancy evolution and no apparent chronic or debilitating conditions, immediately seen after an identified case in the same facility, was considered as a control, until we reached the desired sample size. Women were excluded if they refused to consent for the study or refused to provide a blood sample, or if they had hepato-renal disease, multiple pregnancy, or fetal death in utero.

\subsection{Data Collection}

Before data collection, experienced midwifes and doctors received training on all aspects of the study procedures, from how to complete the study questionnaire, to blood pressure and anthropometric measurements. Phlebotomists were trained on good practice of urine and blood collection techniques, labelling, storage, cold chain maintenance, and transportation procedures.

To standardize the perceptions of pregnant women and minimize biases when collecting data, we have adopted the following operational definitions:

- Regular consumption of milk or milk product derivatives corresponded to the pregnant woman's statement that she consumed one of these products at least once every two days.

- Previous use of modern contraceptive methods meant the use of either a 
condom or an estrogen-progestin contraceptive during the period prior to the current pregnancy.

- ANC follow-up meant having received prenatal care from a nurse or physician for the current pregnancy prior to selection for the study.

- Blood pressure was taken at heart level in the arm by a calibrated OMRON JP N1 Intellisensa (Omron Healthcare Co, Japan) electronic blood pressure monitor.

\subsection{Laboratory Sample Collection, Processing and Analysis}

Blood was collected by venipuncture into $5 \mathrm{~mL}$ tubes (Becton Dickinson, Franklin Lakes, NJ, USA) that contained no anti-coagulant. The sample was left at room temperature for $30 \mathrm{~min}$ to clot and then placed in a cool box containing ice, for transport to Provincial Hospital of North Kivu Laboratory for processing, between 2 and $4 \mathrm{~h}$. Samples were centrifuged at $3000 \mathrm{rpm}$ for ten minutes to separate the serum, which was then aliquoted into $2 \mathrm{~mL}$ cryotubes (Sarstedt, CryoPure ${ }^{\circledR}$ ), stored at $-80^{\circ} \mathrm{C}$. Series of 50 samples were analyzed for serum 25(OH)D, using iChroma II analyser (Boditech Med Inc, South Korea).

Proteinuria was diagnosed at the ANC facility making using dipstick test $\left(\right.$ GEN 10SLG, URISCAN $\left.{ }^{\circledR}\right)$.

\subsection{Data Management and Statistical Analysis}

Data was recorded using Microsoft Excel (Microsoft Corporation, Redmond, WA), Office 2010. Data was checked for normality (Kolmogorov-Smirnov test) and changed into logarithmic scale if necessary. Continuous variables were summarized as mean and standard deviation (SD), or as median and interquartile range for non-normal variables, and as number or percentages for categorical variables. Then the following statistical tests were used: Chi-square test, Fisher's exact test, Student's t-test, Mann-Whitney, and Kruskal-Wallis tests. The ANOVA test or test of variance was used for multiple comparisons with post hoc use of the Bonferroni test. Logistic regression model after stepwise backward removal was used to examine the independent association between different factors and PE, the dependent variable. Statistical analyses were performed using IBM SPSS 23 statistical software, and the statistical significance level was fixed at $p<0.05$.

Preeclampsia was considered severe if SBP was $>160 \mathrm{mmHg}$ and/or DBP $>$ $110 \mathrm{mmHg}$ and moderate if SBP was $140-160 \mathrm{mmHg}$ and/or DBP $90-110$ mmHg. Preeclampsia was considered late when diagnosed after 34 weeks of pregnancy [15].

\section{Results}

\subsection{Participants Characteristics}

With respect to the socio-demographic characteristics considered, there were no significant differences between preeclamptic women and controls in our study population (Table 1). 
Table 1. Distribution of patients according to socio-demographic characteristics.

\begin{tabular}{|c|c|c|c|c|c|}
\hline \multirow{2}{*}{ Characteristics } & & \multicolumn{4}{|c|}{ Pregnant women } \\
\hline & & Control & Case & $p$-value & OR [IC 95\%] \\
\hline \multirow[t]{4}{*}{ Age (years) } & & $28.0 \pm 5.8$ & $29.7 \pm 6.5$ & $0.075^{\star \star}$ & \\
\hline & $<18$ & $3(3.2)$ & $3(3.2)$ & & $0.60[0.10-3.46]$ \\
\hline & $18-34$ & $79(83.2)$ & $68(71.6)$ & & $0.54[0.10-3.08]$ \\
\hline & $\geq 35$ & $13(13.7)$ & $24(25.3)$ & & $2.85[0.325-10.49]$ \\
\hline \multirow[t]{3}{*}{ Residence } & & & & $0.362^{*}$ & \\
\hline & Urban & $73(76.8)$ & $76(80.0)$ & & $1.21[0.60-2.41]$ \\
\hline & Rural & $22(23.2)$ & $19(20.0)$ & & $0.83[0.42-1.66]$ \\
\hline \multirow[t]{5}{*}{ Educational status } & & & & $0.513^{* * *}$ & \\
\hline & $\begin{array}{l}\text { Illiterate. read } \\
\text { and write }\end{array}$ & $13(13.7)$ & $8(8.4)$ & & $0.56[0.19-1.62]$ \\
\hline & Elementary & $17(17.9)$ & $13(13.7)$ & & $1.24[0.40-3.88]$ \\
\hline & Secondary & $44(46.3)$ & $51(53.7)$ & & $1.88[0.72-4.96]$ \\
\hline & university & $21(22.1)$ & $23(24.2)$ & & $1.78[0.62-5.14]$ \\
\hline \multirow[t]{4}{*}{ Marital status } & & & & $0.240^{* * *}$ & \\
\hline & Single & $4(4.2)$ & $6(6.3)$ & & $0.73[0.24-2.20]$ \\
\hline & Married & $89(93.7)$ & $89(93.7)$ & & $1.36[0.45-4.09]$ \\
\hline & Divorced & $2(2.1)$ & $0(0.0)$ & & - \\
\hline \multirow[t]{7}{*}{ Occupational status } & & & & $0.096^{\star * *}$ & \\
\hline & housewife & $56(58.9)$ & $46(48.4)$ & & $0.41[0.12-1.45]$ \\
\hline & Employee & $4(4.2)$ & $15(15.8)$ & & $1.75[0.34-8.98]$ \\
\hline & Pupill student & $5(5.3)$ & $5(5.3)$ & & $0.50[0.09-2.81]$ \\
\hline & Merchant & $6(6.3)$ & $4(4.2)$ & & $0.33[0.06-1.91]$ \\
\hline & Resourcefulness & $20(21.1)$ & $17(17.9)$ & & $0.43[0.11-1.66]$ \\
\hline & Others & $4(4.2)$ & $8(8.4)$ & & $1.22[0.33-4.47]$ \\
\hline Total & & 95 & 95 & & \\
\hline
\end{tabular}

** Student's t-test; ${ }^{* *}$ Pearson Chi-square test; ${ }^{*}$ Fisher's Exact Test.

Information related to lifestyle, obstetrical, clinical and biochemical characteristics is given below (Table 2).

IQR = InterQuartile Range ( 25 \& 75); DBP = Diastolic Blood Pressure; SBP = Systolic Blood Pressure; BMI = Body Mass Index.

Serum Vitamin D levels in preeclamptic patients displayed the following profile: deficient (9.5\%), insufficient (61.1\%), and normal values (only $20 \%$ ).

Overall, there was a statistically significant relationship between PE and the following clinical parameters: personal PE history, primipaternity, personal history of hypertension, family history of hypertension, family history of PE on the spousal side, family history of PE on the maternal side, BMI, and serum vitamin 
Table 2. Distribution of patients according to lifestyle, obstetrical, clinical and biochemical characteristics.

\begin{tabular}{|c|c|c|c|c|c|}
\hline \multirow{2}{*}{ Characteristics } & & \multicolumn{4}{|c|}{ Pregnant women } \\
\hline & & Control & Case & $p$-value ${ }^{*}$ & OR [IC 95\%] \\
\hline & & & & 0.381 & \\
\hline \multirow[t]{2}{*}{ Mode of admission } & Not referred & $63(66.3)$ & $60(63.2)$ & & $0.87[0.48-1.58]$ \\
\hline & Referred & $32(33.7)$ & $35(36.8)$ & & $1.15[0.63-2.08]$ \\
\hline History of HBP & & $4(4.2)$ & $17(17.9)$ & 0.002 & $4.96[1.60-15.36]$ \\
\hline History of prior preeclampsia & & $2(2.1)$ & $19(20.0)$ & $<0.001$ & $11.63[2.63-51.49]$ \\
\hline Contraceptive history & & $17(17.9)$ & $25(26.3)$ & 0.011 & $1.64[0.82-3.29]$ \\
\hline Alcohol intake & & $25(26.3)$ & $23(24.2)$ & 0.434 & $0.89[0.47-1.72]$ \\
\hline Consumption of milk and derivatives & & $72(75.8)$ & $59(62.1)$ & 0.030 & $0.52[0.28-0.98]$ \\
\hline Smoking status & & $5(5.3)$ & $1(1.1)$ & 0.016 & $0.19[0.02-0.67]$ \\
\hline Family history of HBP & & $28(29.5)$ & $42(44.2)$ & 0.025 & $1.90[1.04-3.45]$ \\
\hline Family history of diabetes & & $17(17.9)$ & $17(17.9)$ & 0.575 & $1.00[0.48-2.10]$ \\
\hline Spouse's family history of PE (mother. sisters. aunt) & & $2(2.1)$ & $9(9.5)$ & 0.029 & $4.87[1.02-23.19]$ \\
\hline Maternal family history of PE (Mother. sisters. aunt..) & & $6(6.3)$ & $19(20.0)$ & 0.004 & $3.71[1.41-9.76]$ \\
\hline \multirow[t]{3}{*}{ Primipaternity } & & $4(4.2)$ & $8(8.4)$ & 0.019 & $2.09[1.61-7.20]$ \\
\hline & & $2.0(1.6-3.1)$ & $2.0(1.9-4.1)$ & 0.945 & \\
\hline & Nulliparity & $26(27.4)$ & $28(29.5)$ & & $0.77[0.36-1.64]$ \\
\hline \multirow[t]{4}{*}{ Parity (median and IQR) } & Gravida $(1-3)$ & $29(30.5)$ & $24(25.3)$ & & $0.96[0.38-2.39]$ \\
\hline & Gravida $(4-6)$ & $25(26.3)$ & $30(31.6)$ & & $1.24[0.50-3.10]$ \\
\hline & Gravida $(>6)$ & $15(15.8)$ & $13(13.7)$ & & $1.39[0.56-3.45]$ \\
\hline & & & & 0.103 & \\
\hline \multirow[t]{2}{*}{ History of prior abortion } & Non & $71(74.7)$ & $62(65.3)$ & & $0.64[0.34-1.19]$ \\
\hline & Oui & $24(25.3)$ & $33(34.7)$ & & $1.31[0.90-1.91]$ \\
\hline \multirow[t]{2}{*}{ Antenatal care follow up (ANC) } & & $88(92.6)$ & $81(85.3)$ & 0.048 & $0.46[0.18-1.2]$ \\
\hline & & $25.4 \pm 3.1$ & $27.4 \pm 5.2$ & 0.002 & \\
\hline \multirow{3}{*}{ BMI $\left(\mathrm{kg} / \mathrm{m}^{2}\right)$} & $18.5-24.9$ & $37(49.3)$ & $24(30.8)$ & 0.030 & $0.30[0.11-0.84]$ \\
\hline & $25-29.9$ & $32(42.7)$ & $34(43.6)$ & 0.009 & $1.52[0.75-3.09]$ \\
\hline & $30-35$ & $6(8.0)$ & $20(25.6)$ & 0.002 & $5.07[1.77-14.54]$ \\
\hline SBP & & $111.8 \pm 11.3$ & $167.9 \pm 24.2$ & $<0.001$ & \\
\hline DBP & & $68.2 \pm 9.6$ & $106.7 \pm 18.4$ & $<0.001$ & \\
\hline Gestational age at screening (weeks) & & $34.5 \pm 13.4$ & $34.1 \pm 4.4$ & 0.897 & $1.36[0.21-1.52]$ \\
\hline \multirow[t]{4}{*}{$25[\mathrm{OH}] \mathrm{D}\left(\mathrm{D}_{2}\right.$ et $\left.\mathrm{D}_{3}\right)$ Vitamin $\mathrm{D}$ Median and IQR } & & $28.5(24.9-31.4)$ & $21.7(19.2-24.1)$ & $<0.001$ & \\
\hline & Deficiency & $5(5.3)$ & $9(9.5)$ & 0.005 & $3.60[1.06-5.12]$ \\
\hline & Insufficiency & $52(54.7)$ & $67(70.5)$ & 0.040 & $2.96[1.33-4.97]$ \\
\hline & Normal & $38(40.0)$ & $19(20.0)$ & 0.004 & $0.38[0.2-0.72]$ \\
\hline Total & & 95 & 95 & & \\
\hline
\end{tabular}

${ }^{\star}$ Fisher's Exact Test. IQR = Inter Quartile Range (2 5 \& 75); DBP = Diastolic Blood Pressure; SBP = Systolic Blood Pressure; BMI = Body Mass Index. 
D level, with respective odds ratios ranged from 1.64 to 11.63 times higher than in controls. The BMI mean value in preeclamptic patients was significantly higher than in controls; BMI normal values represented a protective factor (OR $=0.30 ; 95 \%$ CI: $[0.11-0.84])$, while obesity was a real risk factor $(\mathrm{OR}=5.07$; 95\% CI: [1.77 - 14.54]). As expected, mean values for SBP and DBP were higher in preeclamptic patients than in controls. As for vitamin $\mathrm{D}$, whose median concentration was significantly lower in preeclamptic patients, concentrations below the normal value (deficit and insufficiency levels) were significantly more associated with preeclampsia $(\mathrm{OR}=3.60 ; 95 \%$ IC: [1.06 - 5.12] and 2.67; 95\% CI: [1.39 - 5.10], respectively), whereas normal concentrations showed a significant protective effect $(\mathrm{OR}=0.38 ; 95 \% \mathrm{CI}$ : [0.2 - 0.72]). Furthermore, consumption of milk and its derivatives ( $\mathrm{OR}=0.52 ; 95 \% \mathrm{CI}$ : [0.28 - 0.98]), smoking (OR = 0.19; 95\% CI: [(0.02 - 0.67]) and follow-up of ANC (OR = 0.46; 95\% CI: [0.18 - 0.97]) showed a significantly more protective association with regard to preeclampsia.

As for the mode of admission to hospital, only $36.8 \%$ of patients were regularly transferred.

The median gravidity was the same for preeclamptic patients (4.0; IQR: 3.0 5.0) and controls (4.0; IQR: 3.0 - 4.4); besides, there was no difference of average gestational age at screening between them ( $34.1 \pm 4.4$ versus $34.5 \pm 13.4$ weeks).

Proteinuria $\geq 3$ crosses was registered in $48.4 \%$ of preeclamptic patients, and $70.5 \%$ of these presented a clinical picture of severe PE. Based on the gestational age at screening for PE, $61.1 \%$ of patients had developed early PE.

The most common complaints reported by preeclamptic patients were headache $(57.9 \%)$, visual abnormalities (37.9\%) and tinnitus $(30.5 \%)$.

With regard to the clinical course in preeclamptic patients, $5.3 \%$ of the cases progressed to eclampsia.

\subsection{Risk Factors Associated with Preeclampsia}

Table 3. Risk factors associated with preeclampsia.

\begin{tabular}{|c|c|c|c|c|c|}
\hline \multirow{2}{*}{ Characteristics } & & \multicolumn{2}{|c|}{ Bivariate analysis } & \multicolumn{2}{|c|}{ Multivariate analysis } \\
\hline & & $p$-value ${ }^{*}$ & OR (IC95) & $p$-value ${ }^{*}$ & OR (IC95) \\
\hline \multicolumn{6}{|l|}{ Primipaternity } \\
\hline & $N o$ & & 1 & & 1 \\
\hline & Yes & 0.024 & $2.09[1.61-7.20]$ & 0.339 & $1.99[0.48-8.27]$ \\
\hline \multicolumn{6}{|l|}{ History of HBP } \\
\hline & $N o$ & & 1 & & 1 \\
\hline & Yes & 0.006 & $4.96[1.60-15.36]$ & 0.009 & $4.02[1.89-8.05]$ \\
\hline \multicolumn{6}{|l|}{$\begin{array}{l}\text { Past history of } \\
\text { preeclampsia }\end{array}$} \\
\hline & $N o$ & & 1 & & 1 \\
\hline & Yes & 0.001 & $11.63[2.63-15.49]$ & 0.008 & $12.30[1.92-18.98]$ \\
\hline $\begin{array}{l}\text { Consumption of milk } \\
\text { and derivatives }\end{array}$ & \multicolumn{4}{|c|}{ Consumption of milk } & \\
\hline
\end{tabular}




\section{Continued}

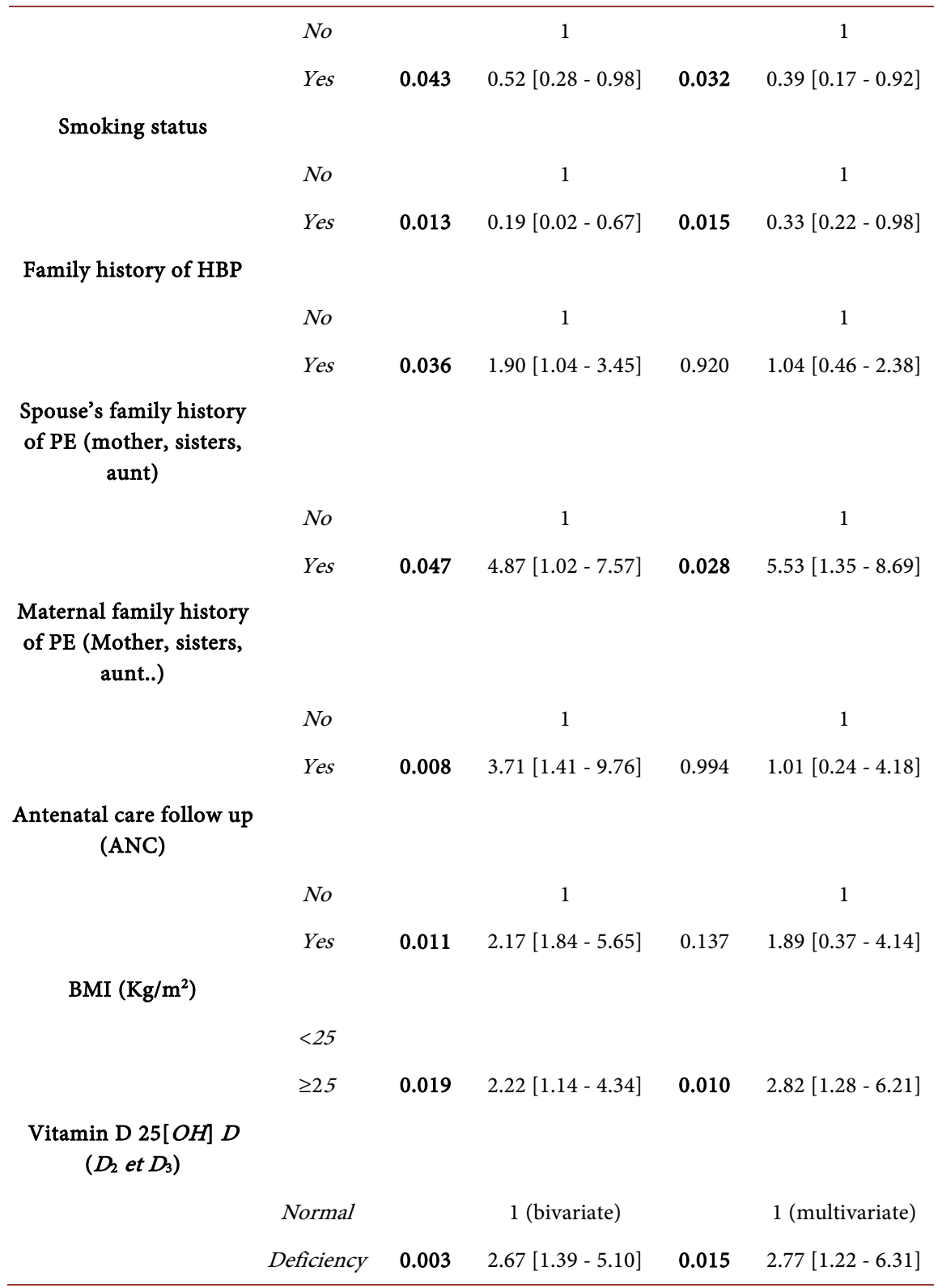

${ }^{\star}$ Logistic regression.

\section{Discussion}

To the best of our knowledge, this is the first time that vitamin D status and risk factors for PE are jointly assed in the DR Congo.

\subsection{Socio-Demographic and Clinical Characteristics}

From the analysis of the socio-demographic parameters (Table 1), an overall observation has been made: there was no statistically significant difference between the two groups, i.e. PE pregnant cases and controls, for the traits investigated.

Although a significant proportion of preeclamptic patients (71.6\%) was found 
in the normal reproductive age group, our study did not show a statistically significant difference. However, both extreme age groups, $<18$ year $(3.2 \%)$ and $>35$ year $(25.3 \%)$, were risk factors. Similar findings with higher values were reported by Essam et al. in Cairo for both [18 - 21 year] (32.0\%) and [26 - 30 year] (41.0\%) age groups [16]. In Kampala, the lowest proportion of preeclamptic women $(17.9 \%)$ was aged 30 year old or older $(\mathrm{OR}=1.58$; 95\% CI: $0.94-2.62)$ [17]. There was no statistically significant difference between the mean ages of preeclamptic cases and controls $(P=0.075)$. For preeclamptic women, the mean age was $29.7 \pm 6.5$ years and more or less similar to that reported by Kiondo et al. (24.07 \pm 5.15 years), Maereg et al. (26.75 \pm 5.08 years), and Merviel et al. (28.6 \pm 1.5 years) [17] [18] [19]. Our findings are in line with reports by Beaufils et al. who argued that the classic double-hump distribution with a peak in very young women under 20 years and a second peak in women over 37 - 40 years of age was no longer observed in several studies except in some developing countries [20].

As regards the relationship between $\mathrm{PE}$ and the residence of pregnant women in this study, the majority of PE women were urban residents, $80 \%$ of whom were from the city of Goma. Significantly, similar rates of $79.0 \%$ were found in Cairo and Addis Ababa [16] [18]. Urban residence appeared to be a protective risk factor in Cairo, and the risk of PE was 4-fold higher among pregnant women living in rural areas [16]. Lack of financial and logistical resources for evacuation of PE women from rural areas may account for the absence of a similar risk profile, then supporting the lower admission rate (limited accessibility) of these rural pregnant women in this study, in comparison with the observations made in Cairo [16].

The majority of the PE pregnant women (77.9\%) in our sample had a high school or university education level, while Essam et al. [16] reported $48.0 \%$ illiteracy in their Cairo study. The difference remained insignificant between levels of education in preeclamptic women and controls in Goma $(p=0.513)$. In Kampala [17], the risk of PE was about 1.31-fold higher for the merged group of primary education and illiterates categories, whereas in Goma it was 1.24-fold higher for the primary level and 0.56-fold lower for the illiterates with no significant difference. It should be noted for our study that the risk of PE was about 2 -fold higher for the high school and university education levels, taken separately but with no significant difference. The high proportion of ANC attendance in both groups (preeclamptic and control) was indubitably due to the influence of level of education. A pregnant woman with higher education level is more likely to see a doctor if her health status is not balanced. The results observed elsewhere would probably be a consequence either of poverty or of gender-based religious discrimination commonly observed in certain states under religious influence, affecting the female gender mainly in the area of formal education.

The difference about occupations observed in preeclamptic women and controls in Goma was found to be insignificant $(p=0.096)$, whereas in Cairo [16] housewives were at greater risk than those in Goma. It is generally admitted that professional qualification is related to the level of education, and education en- 
sures adequate socio-economic status with a lower potential risk of unemployment. In Goma, $48.4 \%$ of preeclamptic women were housewives (unemployed) versus $56 \%$ in Cairo [16] with a similar risk of about 1.75 for both sites, whereas the proportion of illiterates (48\%) in Cairo was higher than in our study (8.4\%). Unemployment-related lack of income may perpetuate early marriages that lead to accelerated reproductive activity with negative impact on socio-economic level. Pregnant women living alone, in this study, were not at risk of PE $(p=0.240)$ compared to the findings in Kampala $(p=0.025)$ [17]. As for the onset of PE, $61.1 \%$ of PE cases were early vs. approximately $10 \%$ by Cunningham et al. [21] who reported that high proportions were observed beyond $34^{\text {th }}$ week and even during delivery or postpartum.

The mean gestational age at screening was $34.1 \pm 4.4$ weeks compared with $35.83 \pm 3.7$ weeks found in Addis Ababa [18].

PE clinical manifestations of the disease were highly variable. However, considering order of frequency in the literature, headache and visual disturbances followed by abdominal pain, altered consciousness and dyspnea have been noted. Like Sibai et al. [22], we found the same order of frequency with headache and then visual disturbances.

Bivariate analysis (Table 2) revealed the following risk factors for PE in our study: primipaternity, personal history of hypertension, personal history of $\mathrm{PE}$, history of hypertension in the immediate family, history of PE in the immediate family (husband and/or pregnant side), lack of ANC follow-up, BMI $\geq 25 \mathrm{Kg} / \mathrm{m}^{2}$ and vitamin $\mathrm{D}$ deficiency and insufficiency, while dairy consumption and smoking had emerged as protective factors against PE. After adjusting by multivariate analysis, personal history of hypertension, $\mathrm{PE}$ and family history of $\mathrm{PE}$ (husband's side), and vitamin D deficiency and insufficiency $(<30 \mathrm{ng} / \mathrm{mL}$ ) persisted as independent risk factors for PE (Table 3). In contrast, dairy consumption and smoking also independently reduced the risk of PE. Therefore, all of the above factors should be considered as determinants of PE for this study.

Regarding the history of PE (Table 2 \& Table 3 ) and except the study conducted in Cairo [16] with a calculated risk estimated at 2.85-fold higher, many authors have found similar results ranging from 5.08 [23] to 8.4 [24], 8.12 [19], and 12.30-fold higher for our sample. Genetic factors are involved in the etiology of PE. Studies of candidate genes have provided evidence, although controversial, of links to several genes, including the gene coding for angiotensinogen located on 1q42-43 and eNOS (Endothelial NOS or nitric oxide synthase 3) on 7q36. The authors note that the locus related to Preeclampsia/Eclampsia is located on chromosome $2 \mathrm{p}$ [25] [26].

The influence of personal history of HBP (Table 2 \& Table 3 ) seems to be unanimously reported in the literature regarding its predictive power as highlighted in studies conducted in Kampala [17], Amiens [19], California [27], Goma (this study) and even in the systematic review by Duckitt K. et al. [34]. The OR values observed by these authors vary from 2.3 to 5.1 . 
Family history of PE on the pregnant woman's side and more on the husband's side are significant determinants; Merviel P. et al. [19] and Duckitt K. et al. [24] confirmed this risk in terms of overall family history with OR values of 1.04 and 2.90, respectively. In the present study, the husband's family displayed a 5 -fold higher risk.

These results support the hypothesis that the genotype of the fetus contributes to the overall risk of preeclampsia. Our results confirm studies that have suggested a paternal component in the genetic predisposition to PE. Some genes involved in the development of PE, such as the T235 allele of the angiotensinogen, the Factor V Leiden mutation and variants of the methylenetetrahydrofolate reductase gene, may be paternal in origin. There is evidence of increased incidence of PE as a result of maternal and/or paternal genetic predisposition [28].

\subsection{BMI, Tobacco and Diet}

Consistent results have been reported regarding the association between overweight and obesity on the one hand and PE on the other hand: A 2-fold increased risk was reported for obesity in Kampala [17], and a 3-fold increased risk by Duckitt [24]. Like obesity, overweight also confers a risk of 2.5 for Merviel [19], 2.1 for Duckitt [24] and 2.82 in Goma. O'Brien reports that the risk of preeclampsia has generally doubled with each 5 to $7 \mathrm{~kg} / \mathrm{m}^{2}$ increase in body mass index before pregnancy [29]. In Maya females, women with a higher prepregnancy BMI have a higher risk of PE than those with a normal pregnancy $(\mathrm{RR}=$ 2.82; $p=0.008$ for overweight and $\mathrm{RR}=4.22 ; p=0.001$ for obesity) [30].

Obesity would probably increase the risk of PE by inducing chronic inflammation along with endothelial dysfunction which together may mutualize with placental antiangiogenic factors to induce microangiopathic pathology, phenomena that characterize PE [31] [32].

Tobacco use and dairy consumption were characterized by a seemingly protective potential with regard to the results of our study (Table 3). Similar findings for tobacco alone were found in Amiens by Merviel [19], in Cairo [16] and in Kampala [17].

The debate triggered by the protective role of smoking remains topical due to various mechanisms that are contradictory in some respects. This role is controversial: on one hand, some authors consider the carbon monoxide $(\mathrm{CO})$ role in cigarette smoking. Indeed, $\mathrm{CO}$ increases trophoblastic invasion and remodelling of the uterine arteries, decreases the local inflammatory response, increases placental blood flow through a vasodilator effect, decreases apoptosis phenomena at the level of the syncytiotrophoblast and finally could bind to nitrogen monoxide (NO) receptors. In addition, it has recently been described that smoking induces a higher serum PlGF (Placenta Growth Factor) level, which would promote good placental development and thus effectively counteract predisposition to $\mathrm{PE}$ [33]. This hypothesis seems interesting since it explains the involvement of $\mathrm{CO}$ (carbon monoxide) from the placental level before the 
onset of endothelial disorders. However, it is weakened by the deleterious effects of tobacco, which is reputed to be a risk factor for cardiovascular disease, type II diabetes and numerous unfavourable pregnancy outcomes such as prematurity, low birth weight, intrauterine growth retardation, placental abruption, retro-placental hematomas, perinatal and maternal mortality [34] [35] [36].

Regular consumption of milk or its declared derivatives would act through the proven richness of milk in calcium, i.e. $117 \mathrm{mg} / 100 \mathrm{~g}$. It has been shown that providing women with a calcium supplementation during the second half of pregnancy reduces their risk of high blood pressure, proteinuria, and other related problems such as seizures, stroke, clotting disorders, pulmonary edema, kidney failure, and even death. As the proposed biological mechanism for the relationship between calcium and blood pressure is not yet fully confirmed, the vascular and immunological effects of calcium are suspected [37] [38].

\subsection{Vitamin D}

Taken separately, the 3 categories of vitamin D concentration (i.e. deficiency, insufficiency and normal conditions) showed an increasing risk from the condition of insufficiency $(\mathrm{OR}=2.96)$ to that of deficiency ( $\mathrm{OR}=3.60)$ with $70.5 \%$ and $9.5 \%$ of PE patients, respectively. The group referred to as "low level", in the present study, is a combination of these two categories. Patients in this group were three times more likely to have PE than patients with normal vitamin D levels in our study population ( $\mathrm{AOR}=2.77 ; 95 \% \mathrm{CI}[1.22-6.31]$ ).

It should be noted, however, that the results on vitamin $\mathrm{D}$ levels (in other studies) remain divergent in the literature: some authors have found no relationship between vitamin D deficiency measured in early pregnancy and PE [39] [40] [41]; for others there is a clear relationship when measured in late pregnancy [42] [43] [44]. The first aforementioned authors [43] [44] [45], were convinced that the risk of $\mathrm{PE}$ appears to depend on the time (at the beginning or at the end of pregnancy depending on the season) for vitamin $\mathrm{D}$ assay. Considering this hypothesis to be true, what would be the results observed in regions such as ours with almost permanent sunny periods?

It has been observed that the level of enzymes involved in the synthesis of vitamin D (24-hydroxylase and 1-alpha-hydroxylase) is not influenced by the season even though vitamin D levels were found to be low in winter when PE occurred in summer or spring [46] [47] [48].

\section{Limitations}

Many other risk factors found in the literature were not incorporated into our study due to uncertainty about the sincerity and accuracy of the responses to be given by the couple and the lack of locally Assisted Human Reproduction units.

As the vitamin $\mathrm{D}$ dosage may vary with the gestational age according to some authors, our assessment only took into account the moment of inclusion of the pregnant woman in the study. We did not standardize the timing of dosing. Be- 
sides, we have not had white pregnant women or other racial groups in our study population. However, the study has the advantage of having covered all categories of pregnant women in our environment and to have done the dosage according to the procedure.

\section{Authors' Contributions}

Kabuyanga Kabuseba contributed to the preparation of the manuscript of this article from the outset as principal investigator. Dr. Balungwe participated in the data collection. Professors Lundimu, Elongi, Kalenga and Kakoma critically reviewed the manuscript, edited and corrected the text from the proposal to the development of this manuscript. All authors have read and approved the final manuscript.

\section{Acknowledgements}

We give thanks particularly to Professor Alexandra Benachi of the Maternity Department of the Hôpital Necker-Enfants in Paris for her support and valuable advice during the design of this study (for clinical trial purpose), to the laboratory agents of the Provincial Referral Hospital of North Kivu in Goma and to the team (Doctors and Nurses) who collaborated for the prospective data collection.

\section{Conflicts of Interest}

There is no conflict of interest.

\section{References}

[1] American College of Obstetricians and Gynecologists (ACOG) (2019) Practice Bulletin No. 202: Gestational Hypertension and Preeclampsia. Obstetrics \& Gynecology, 133, e1-e25. https://doi.org/10.1097/AOG.0000000000003018

[2] Abalos, E., Cuesta, C., Grosso, A.L., et al. (2013) Global and Regional Estimates of Preeclampsia and Eclampsia: A Systematic Review. European Journal of Obstetrics \& Gynecology and Reproductive Biology, 170, 1-6. https://doi.org/10.1016/j.ejogrb.2013.05.005

[3] Osungbade, K.O. and Ige, O.K. (2011) Public Health Perspectives of Preeclampsia in Developing Countries: Implication for Health System Strengthening. Journal of Pregnancy, 2011, Article ID: 481095. https://doi.org/10.1155/2011/481095

[4] OMS (2013) Recommandations de l'OMS pour la Prévention et le Traitement de la Pré-éclampsie et de l'éclampsie-Implications et actions.

[5] Hod, T., Cerdeira, A.S. and Karumanchi, S.A. (2015) Molecular Mechanisms of Preeclampsia. Cold Spring Harbor Perspectives in Medicine, 5, a023473. https://doi.org/10.1101/cshperspect.a023473

[6] Karumanchi, S.A., Lim, K.H. and Phyllis, A. (2019) Preeclampsia: Pathogenesis. https://www.uptodate.com/contents/preeclampsia-pathogenesis/print?search=preec lampsia\&topicRef $=6825 \&$ source $=$ see link

[7] Romero, R. and Chaiworapongsa, T. (2013) Preeclampsia: A Link between Trophoblast Dysregulation and an Antiangiogenic State. Journal of Clinical Investigation, 123, 2775-2777. https://doi.org/10.1172/JCI70431 
[8] Phyllis, A. and Sibai, B.M. (2019) Preeclampsia: Clinical Features and Diagnosis. https://www.uptodate.com/contents/preeclampsia-clinical-features-anddiagnosis?se arch $=$ preeclampsia\&topicRef $=6825 \&$ source $=$ see link

[9] Norwitz, E.R. (2019) Preeclampsia: Management and Prognosis. https://www.uptodate.com/contents/preeclampsia-management-and-prognosis?sea $\underline{\mathrm{rch}=\text { preeclampsia\&topicRef }=6814 \& \text { source }=\text { see link }}$

[10] Souberbielle, J.C., Prie, D., Courbebaisse, M., et al. (2008) Actualité sur les effets de la vitamine $\mathrm{D}$ et l'évaluation du statut vitaminique D. Annales d' Endocrinologie, 69, 501-510. https://doi.org/10.1016/j.ando.2008.07.010

[11] Benachi, A., Cordier, A., Courbebaisse, M., et al. (2012) Vitamine D, obstétrique et prééclampsie. La Lettre du Gynécologue, 375, 25-27.

[12] De-Regil, L.M., Palacios, C., Ansary, A., Kulier, R. and Peña-Rosas, J.P. (2016) Vitamin D Supplementation for Women during Pregnancy. Sao Paulo Medical Journal, 134, 274-275. https://doi.org/10.1590/1516-3180.20161343T2

[13] Observatoire Volcanologique de Goma. Rapport Annuel 2018.

[14] Elongi, J.P., Tandu, B., Spitz, B., et al. (2011) Influence de la variation saisonnière sur la prévalence de la prééclampsie à Kinshasa. Gynécologie Obstétrique \& Fertilité, 39, 132-135. https://doi.org/10.1016/j.gyobfe.2010.12.010

[15] Pottecher, T., Luton, D., Zupan, V., et al. (2009) Prise en charge multidisciplinaire des formes graves de prééclampsie (SFAR: Société française d'anesthésie et de réanimation CNGOF: Collège national des gynécologues et obstétriciens français SFNN: Société française de néonatologie SFMP: Société française de médecine périnatale).

[16] Essam, A.E., Hamed, O.K., Soliman, M.A., et al. (2011) Risk Factors and Impacts of Pre-Eclampsia: An Epidemiological Study among Pregnant Mothers in Cairo. Egypt. Journal of American Science, 7, 311-323.

[17] Kiondo, P., Wamuyu-Maina, G., Wandabwa, J., et al. (2014) The Effects of Vitamin C Supplementation on Pre-Eclampsia in Mulago Hospital, Kampala, Uganda: A Randomized Placebo Controlled Clinical Trial. BMC Pregnancy and Childbirth, 14, 283. https://doi.org/10.1186/1471-2393-14-283

[18] Maereg, W., Dessalegn, M., Worku, A., et al. (2016) Trends of Preeclampsia/Eclampsia and Maternal and Neonatal Outcomes among Women Delivering in Addis Ababa Selected Government Hospitals, Ethiopia: A Retrospective Cross-Sectional Study. The Pan African Medical Journal, 25, 12.

[19] Merviel, P., Touzart, L., Deslandes, V., et al. (2008) Risk Factors of Preeclampsia in Single Pregnancy. Journal de Gynécologie Obstétrique et Biologie de la Reproduction, 37, 477-482. https://doi.org/10.1016/j.jgyn.2008.04.001

[20] Beaufils, M., Larget, D., Chrétien, J., et al. (1983) Hypertensions artérielles gravidi-ques et médecine préventive. Étude des facteurs étiologiques et du pronostic à moyen terme dans 442 cas. Bulletin de L'Académie Nationale de Médecine, 167, 413-419.

[21] Cunningham, F.G. and Lindheimer, M.D. (1992) Hypertension in Pregnancy. The New England Journal of Medicine, 326, 927-932. https://doi.org/10.1056/NEJM199204023261405

[22] Sibai, B.M. (1988) Pitfalls in Diagnosis and Management of Preeclampsia. American Journal of Obstetrics \& Gynecology, 159, 1-5. https://doi.org/10.1016/0002-9378(88)90482-6

[23] Deis, S., Rouzier, R., Kayem, G., et al. (2008) Development of a Monogram to Pre- 
dict Occurrence of Preeclampsia. European Journal of Obstetrics \& Gynecology and Reproductive Biology, 137, 146-151. https://doi.org/10.1016/j.ejogrb.2007.05.022

[24] Duckitt, K. and Harrington, D. (2005) Risk Factors for Preeclampsia at Antenatal Booking: Systematic Review of Controlled Studies. BMJ, 330, 565.

https://doi.org/10.1136/bmj.38380.674340.E0

[25] Van Dijk, M., Mulders, J., Poutsma, A., et al. (2005) Maternal Segregation of the Dutch Preeclampsia Locus at 10q22 with a New Member of the Winged Helix Gene Family. Nature Genetics, 37, 514-519. https://doi.org/10.1038/ng1541 https://www.researchgate.net/deref/http\%3A\%2F\%2Fdx.doi.org\%2F10.1038\%2Fng1 $\underline{541}$

[26] Klungsøyr, K., Morken, N.H., Irgens, L., et al. (2012) Secular Trends in the Epidemiology of Pre-Eclampsia throughout 40 Years in Norway: Prevalence, Risk Factors and Perinatal Survival. Paediatric and Perinatal Epidemiology, 26, 190-198. https://doi.org/10.1111/j.1365-3016.2012.01260.x

[27] Yanit, K.E., Snowden, J.M., Cheng, Y.W., et al. (2012) The Impact of Chronic Hypertension and Pregestational Diabetes on Pregnancy Outcomes. American Journal of Obstetrics \& Gynecology, 207, 333e1-6. https://doi.org/10.1016/j.ajog.2012.06.066

[28] Esplin, M.S., Fausett, M.B., Fraser, A., Kerber, M.G., Carrillo, J. and Varner, M.W. (2001) Paternal and Maternal Components of the Predisposition to Preeclampsia. The New England Journal of Medicine, 344, 867-872. https://doi.org/10.1056/NEJM200103223441201

[29] O’Brien, T.E., Ray, J.G. and Chan, W.S. (2003) Maternal Body Mass Index and the Risk of Preeclampsia: A Systematic Overview. Epidemiology, 14, 368-374. https://doi.org/10.1097/01.EDE.0000059921.71494.D1

[30] Canto-Cetina, T., Coral-Vázquez, R.M., Rojano-Mejía, D., et al. (2018) Higher Prepregnancy Body Mass Index Is a Risk Factor for Developing Preeclampsia in Maya-Mestizo Women: A Cohort Study. Ethnicity \& Health, 23, 682-690. https://doi.org/10.1080/13557858.2017.1315367

[31] Zera, C.A., Seely, E.W., Wilkins-Haug, L.E., et al. (2014) The Association of Body Mass Index with Serum Angiogenic Markers in Normal and Abnormal Pregnancies. American Journal of Obstetrics \& Gynecology, 211, 247.e1-247.e7. https://doi.org/10.1016/j.ajog.2014.03.020

[32] Gabory, A., Chavatte-Palmer, P., Vambergue, A, et al. (2016) Impact de l'obésité et du diabète maternels sur la fonction placentaire. Médecinel Sciences, 32, 66-68. https://www.researchgate.net/deref/http\%3A\%2F\%2Fdx.doi.org\%2F10.1051\%2Fme dsci\%2F20163201011

[33] Llurba, E., Sánchez, O., Domínguez, C., et al. (2013) Smoking during Pregnancy: Changes in Mid-Gestation Angiogenic Factors in Women at Risk of Developing Preeclampsia According to Uterine Artery Doppler Findings. Hypertens Pregnancy, 32, 50-59. https://doi.org/10.3109/10641955.2012.704107

[34] Tran, T.C. (2016) Impact des facteurs environnementaux sur la survenue d'une prééclampsie sévère. Gynécologie et obstétrique. Université Paris-Saclay. Français.

[35] Conde-Agudelo, A. and Belizán, J.M. (2000) Risk Factors for Pre-Eclampsia in a Large Cohort of Latin American and Caribbean Women. BJOG: An International Journal of Obstetrics \& Gynaecology, 107, 75-83. https://doi.org/10.1111/j.1471-0528.2000.tb11582.x

[36] Cnattingius, S., Mills, J.L., Yuen, J., et al. (1997) The Paradoxical Effect of Smoking in Preeclamptic Pregnancies: Smoking Reduces the Incidence But Increases the 
Rates of Perinatal Mortality, Abruption Placentae, and Intrauterine Growth Restriction. American Journal of Obstetrics and Gynecology, 177, 156-161. https://doi.org/10.1016/S0002-9378(97)70455-1

[37] Omotayo, M.O., Dickin, K.L., Kimberly, O., et al. (2016) Calcium Supplementation to Prevent Preeclampsia: Translating Guidelines into Practice in Low-Income Countries. American Society for Nutrition. Advances in Nutrition, 7, 275-258. https://doi.org/10.3945/an.115.010736

[38] Hofmeyr, G.J., Belizan, J.M. and von Dadelszen, P. (2014) Low-Dose Calcium Supplementation for Preventing Pre-Eclampsia: A Systematic Review and Commentary. BJOG, 121, 951-957. https://doi.org/10.1111/1471-0528.12613

[39] Powe, C.E., et al. (2010) First Trimester Vitamin D, Vitamin D Binding Protein, and Subsequent Preeclampsia. Hypertension, 56, 758-763. https://doi.org/10.1161/HYPERTENSIONAHA.110.158238

[40] Schneuer, F.J., et al. (2014) Effects of Maternal Serum 25-Hydroxyvitamin D Concentrations in the First Trimester on Subsequent Pregnancy Outcomes in an Australian Population. American Journal of Clinical Nutrition, 99, 287-295. https://doi.org/10.3945/ajcn.113.065672

[41] Yu, C.K.H., Ertl, R., Skyfta, E., et al. (2013) Maternal Serum Vitamin D Levels at 11-13 Weeks of Gestation in Preeclampsia. Journal of Human Hypertension, 27, 115-118. https://doi.org/10.1038/jhh.2012.1

[42] Pena, H.R., De Lima, M.C., Brandt, K.G., et al. (2015) Influence of Preeclampsia and Gestational Obesity in Maternal and Newborn Levels of Vitamin D. BMC Pregnancy Childbirth, 15, 112. https://doi.org/10.1186/s12884-015-0547-7

[43] Aghajafari, F., et al. (2013) Association between Maternal Serum 25-Hydroxyvitamin D Level and Pregnancy and Neonatal Outcomes: Systematic Review and Meta-Analysis of Observational Studies. BMJ, 346, f1169. https://doi.org/10.1136/bmj.f1169

[44] Baker, A.M., Haeri, S., Camargo, C.A., et al. (2010) A Nested Case-Control Study of Midgestation Vitamin D Deficiency and Risk of Severe Preeclampsia. The Journal of Clinical Endocrinology \& Metabolism, 95, 5105-5109. https://doi.org/10.1210/jc.2010-0996

[45] Algert, C.S., Roberts, C.L., Shand, A.W., et al. (2010) Seasonal Variation in Pregnancy Hypertension Is Correlated with Sunlight Intensity. American Journal of $O b$ stetrics \& Gynecology, 203, 215.e1-215.e5. https://doi.org/10.1016/j.ajog.2010.04.020

[46] Bernstein, K., Mongeon, I.M., et al. (2004) Seasonal Variation in Preeclampsia Based on Timing of Conception. Obstetrics \& Gynecology, 104, 1015-1020. https://doi.org/10.1097/01.AOG.0000143306.88438.cf

[47] Rudra, C.B. and Williams, M.A. (2005) Monthly Variation in Preeclampsia Prevalence: Washington State, 1987-2001. Journal of Maternal-Fetal and Neonatal Medicine, 18, 319-324. https://doi.org/10.1080/14767050500275838

[48] Morikawa, M., et al. (2014) Seasonal Variation in the Prevalence of Pregnancy-Induced Hypertension in Japanese Women. Journal of Obstetrics and Gynaecology Research, 40, 926-931. https://doi.org/10.1111/jog.12304 